\title{
Perubahan Kecepatan Subduksi Lempeng Indo-Australia terhadap Lempeng Sundaland akibat Gempa Bumi Samudera Hindia tahun 2016
}

\author{
Satrio Muhammad Alif ${ }^{1 *}$ Muhamad Sofyan Sauri ${ }^{1}$, Redho Surya Perdana ${ }^{1}$
}

${ }^{1}$ Teknik Geomatika, Institut Teknologi Sumatera, Terusan Ryacudu, Lampung Selatan, Indonesia

\begin{abstract}
Abstrak
Gempa bumi Samudera Hindia terjadi pada tanggal 2 Maret 2016 dengan magnitudo 7.8 di sekitar zona subduksi Lempeng Sundaland. Implikasi tektonik dari gempa bumi dengan magnitudo di atas 7 ini diteliti karena implikasi tektonik gempa bumi di Samudera Hindia tahun 2012 sangat besar hingga Pulau Jawa. Penelitian ini bertujuan mendapatkan pengaruh gempa bumi Samudera Hindia tahun 2016 terhadap perubahan kecepatan subduksi. Data yang digunakan adalah data Global Navigation Satellite System (GNSS) kontinu di tujuh stasiun yang berada di Lempeng Indo-Australia dan Lempeng Sundaland. Data diolah dengan perangkat lunak ilmiah untuk mendapat solusi koordinat harian. Pada deret waktu koordinat, dilakukan perhitungan kecepatan degan regresi linier untuk data sebelum gempa bumi dan data setelah gempa bumi. Nilai kecepatan yang diperoleh digunakan untuk perhitungan regangan. Hal yang didapatkan dan dibahas adalah perubahan nilai kecepatan dan regangan, serta membandingkan arah kecepatan stasiun GNSS dengan arah kecepatan dari lempeng terkait. Kecepatan stasiun GNSS yang diperoleh berkisar 18 hingga 70 mm/tahun. Kecepatan stasiun GNSS mengalami penurunan dan regangan mengalami pertambahan nilai pemendekan setelah gempa bumi. Nilai perubahan semakin besar untuk stasiun yang lebih dekat ke Palung Sunda. Stasiun GNSS yang berada di pulau di sebelah barat Pulau Sumatra diduga berada di Blok Sumatra, pecahan dari Lempeng Sundaland.
\end{abstract}

Kata kunci: gempa bumi; kecepatan; lempeng; regangan; subduksi.

\begin{abstract}
The Indian Ocean earthquake occurred on March 2, 2016 with a magnitude of 7.8 around the subduction zone of the Sundaland plate. The tectonic implications of an earthquake with a magnitude of 7 are studied due to a very large earthquake in the Indian Ocean in 2012 affects up to the island of Java. This study aims to determine the effect of the 2016 Indian Ocean earthquake on changes in subduction velocity. The data used is continuous Global Continuous Satellite System (GNSS) data at seven stations located on the Indo-Australian Plate and the Sundaland Plate. The data is processed by scientific software to get the daily coordinate solution. The time series coordinates were calculated using linear regression for the data before the earthquake and the data after the earthquake. Velocity values used for strain calculations. The change in velocity and strain values, as well as the directional velocity of the GNSS station are discussed. The obtained GNSS station speed ranges from 18 to 70 $\mathrm{mm} / \mathrm{year}$ The velocity of the GNSS station has decreased and the strain has increased in shortening values after the earthquake. The GNSS station on an island to the west of Sumatra Island is presumed located in the Sumatran Block, a fragment of the Sundaland Plate.
\end{abstract}

Keywords: earthquake; velocity; plate; strain; subduction.

\footnotetext{
*) Korespondensi : satrio.muhammad@gt.itera.ac.id

Diajukan : 24 Agustus 2021

Diterima : 29 November 2021

Diterbitkan : 3 Desember 2021
} 


\section{PENDAHULUAN}

Subduksi merupakan pertemuan antara dua lempeng yang saling bertemu dan salah satu lempeng masuk ke bawah lempeng lainnya. Lempeng yang masuk ke bawah lempeng lainnya disebut slab akan membentuk wilayah zona subduksi dengan banyak gempa bumi yang terjadi dan merupakan salah satu tantangan besar dalam ilmu sains kebumian (Stern, 2002). Salah satu model slab terkini yang digunakan di seluruh zona subduksi merupakan model Hayes dkk. (2018). Model subduksi dibentuk dari data seismik, sedangkan kecepatan subduksi didapatkan dari data GPS kontinu (Devoti dkk., 2011). Model dan kecepatan subduksi merupakan dua parameter penting untuk menentukan potensi bencana seismik di zona subduksi (Griffin dkk., 2019). Salah satu zona subduksi terbentuk di antara pertemuan Lempeng Indo-Australia dan Lempeng Sundaland.

Subduksi Lempeng Indo-Australia ke bawah Lempeng Sundaland terjadi dari Laut Andaman sepanjang Palung Sunda hingga Nusa Tenggara sepanjang Palung Jawa (McCaffrey, 2009). Kecepatan subduksi di zona subduksi tersebut yaitu sebesar 44 hingga $48 \mathrm{~mm}$ setiap tahunnya (DeMets dkk., 2010). Kecepatan subduksi dapat berubah ketika terjadi gempa bumi (Wang dkk., 2012). Gempa bumi yang terjadi di sekitar zona subduksi Lempeng Sundaland yaitu gempa bumi Samudera Hindia tanggal 2 Maret 2016 dengan magnitudo 7.8. Episenter gempa bumi tersebut ditunjukkan pada Gambar 1 dengan bola pantai berwarna hitam, sedangkan garis hitam pada Gambar 1 menunjukkan batas lempeng. Gempa bumi tersebut yang memilki kedalaman $24 \mathrm{~km}$ dan terjadi pukul 12:49 UTC, merupakan gempa bumi yang terjadi di sesar geser mengiri di dalam Lempeng Indo-Australia (Heidarzadeh dkk., 2017). Mekanisme gempa bumi yang sering terjadi di sekitar episenter adalah sesar geser dan menimbulkan tsunami seperti pada gempa bumi Samudera Hindia tahun 2012 dengan magnitudo (M) 8.6 (Maulida dkk., 2016).

Data Global Navigation Satellite System (GNSS) dari stasiun kontinu yang berada di sekitar batas Lempeng Indo-Australia dan Lempeng Sundaland merupakan data yang diperlukan untuk mengamati perubahan kecepatan subduksi. Penggunaan data GNSS terbukti dapat digunakan untuk penelitian gempa

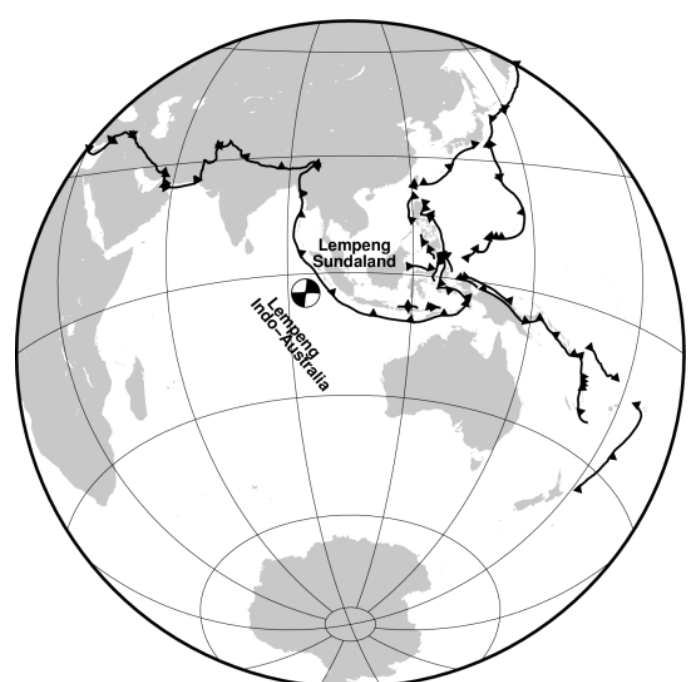

Gambar 1. Episenter gempa bumi yang terjadi di sekitar zona subduksi Lempeng Indo-Australia dan Lempeng Sundaland.

bumi di zona subduksi Lempeng Indo-Australia dan Lempeng Sundaland seperti di Selat Sunda (Alif dkk., 2021a), di Yogyakarta (Pinasti dkk., 2019) dan di Aceh (Pratama dkk., 2017). Penelitian ini penting dilakukan untuk mendapatkan implikasi tektonik dari gempa bumi dengan magnitudo di atas 7. Gempa bumi di Samudera Hindia yang terjadi pada 4 tahun sebelumnya memberikan implikasi tektonik yang sangat besar hingga Pulau Jawa (Alif dkk., 2016). Selain itu, penelitian dari gempa bumi Samudera Hindia tahun 2016 belum ada yang menggunakan data GNSS di zona subduksi. Penelitian ini bertujuan mendapatkan pengaruh gempa bumi Samudera Hindia tahun 2016 terhadap perubahan kecepatan subduksi menggunakan data GNSS di Lempeng IndoAustralia dan Lempeng Sundaland.

\section{METODOLOGI}

Penelitian ini menggunakan data GNSS kontinu di dua stasiun yang berada di Lempeng IndoAustralia dan lima stasiun yang berada di Lempeng Sundaland. Persebaran stasiun ditunjukkan pada Gambar 2. Garis hitam menunjukkan sesar Sumatra (Alif dkk., 2020a). Lima stasiun yang berada di Lempeng Sundaland dikelola oleh Earth Observatory of Singapore (EOS) (McLoughlin dkk., 2011), sedangkan dua stasiun yang berada di Lempeng Indo-Australia merupakan stasiun yang dikelola International GNSS Service (IGS) (Johnson dkk., 2017). Rincian lokasi dari stasiun yang digunakan ditunjukkan pada Tabel 1. Data yang 
digunakan adalah data sebelum gempa bumi sejak 2015 dan data setelah gempa bumi hingga 2019. Stasiun yang berada di Lempeng Sundaland merupakan stasiun yang paling dekat dengan Palung Sunda yang terletak di Provinsi Sumatra Barat, Provinsi Bengkulu, dan Provinsi Lampung.

Data dari stasiun GNSS diolah dengan perangkat lunak ilmiah untuk mendapat koordinat dengan solusi harian. Data GNSS diolah menggunakan perangkat lunak GAMIT (Herring dkk., 2010) dengan menggunakan data pendukung seperti model pasang surut bumi dan laut, model ionosfer, dan parameter orientasi bumi. Pengolahan data menerapkan metode diferensial dengan menggunakan 10 stasiun ikat IGS yaitu LHAZ, USUD, GMSD, PIMO, DGAR, KARR, DARW, ALIC, CEDU, NTUS). Diagram alir dari penelitian ini ditunjukkan pada Gambar 3.

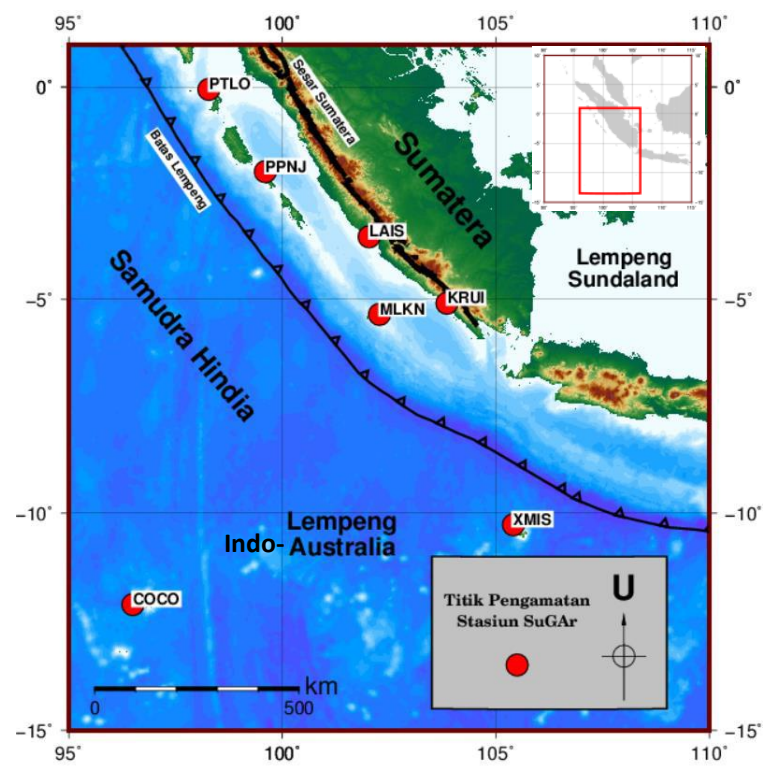

Gambar 2. Persebaran stasiun GNSS yang digunakan.

Tabel 1. Rincian data GNSS yang digunakan

\begin{tabular}{cccc}
\hline $\begin{array}{c}\text { Nama } \\
\text { Stasiun }\end{array}$ & $\begin{array}{c}\text { Lintang } \\
\left(\boldsymbol{(}^{\mathbf{}}\right.\end{array}$ & $\begin{array}{c}\text { Bujur } \\
(\boldsymbol{\circ})\end{array}$ & Lokasi \\
\hline PTLO & $-0,0546$ & 98,2801 & Pulau Tello \\
KRUI & $-5,0902$ & 103,8547 & Krui \\
PPNJ & $-1,9939$ & 99,6037 & Pulau Panjang \\
MLKN & $-5,3526$ & 102,2765 & Pulau Enggano \\
LAIS & $-3,5292$ & 102,0339 & Lais \\
COCO & $-12,1883$ & 96,8339 & $\begin{array}{c}\text { Kepulauan } \\
\text { Cocos }\end{array}$ \\
XMIS & $-10,4499$ & 105,6885 & Pulau Christmas \\
\hline
\end{tabular}

Perhitungan kecepatan dari stasiun GNSS dilakukan pada rentang waktu sebelum gempa bumi dan rentang waktu setelah gempa bumi. Koordinat yang diperoleh dari pengolahan data GNSS mengacu ke ITRF2014 (Altamimi dkk., 2016). Kecepatan dari stasiun GNSS dihitung menggunakan koordinat dalam dua komponen: north-south (NS) component dan east-west (EW) component. Nilai kecepatan diperoleh dengan menggunakan metode kuadrat terkecil (Alif dkk., 2020b) dari regresi linier yang dilakukan pada deret waktu koordinat tanpa outlier. Outlier yang dihapus menggunakan batas tingkat kepercayaan $95 \%$. Persamaan dari perhitungan kecepatan ditunjukkan pada persamaan (1).

$$
y(t)=a t+b
$$

Keterangan dari persamaan (1), adalah $y(t)$ merupakan koordinat pada epok $t, t$ adalah epok dari koordinat, $a$ adalah nilai kecepatan, dan $b$ adalah nilai offset. Waktu yang digunakan untuk memisahkan rentang waktu sebelum gempa bumi dan rentang waktu setelah gempa bumi adalah tanggal 12 Maret 2016 atau Day of Year (DOY) 72 pada tahun 2016.

Kecepatan dari stasiun GNSS digunakan dalam perhitungan regangan untuk mendapatkan perubahan kecepatan subduksi Lempeng IndoAustralia terhadap Lempeng Sundaland. Regangan dihitung pada centroid dari segitiga yang menghubungkan tiga stasiun GNSS. Regangan utama dihitung menggunakan regangan normal dan regangan geser yang diperoleh dari nilai kecepatan stasiun GNSS (Alif dkk., 2021b).

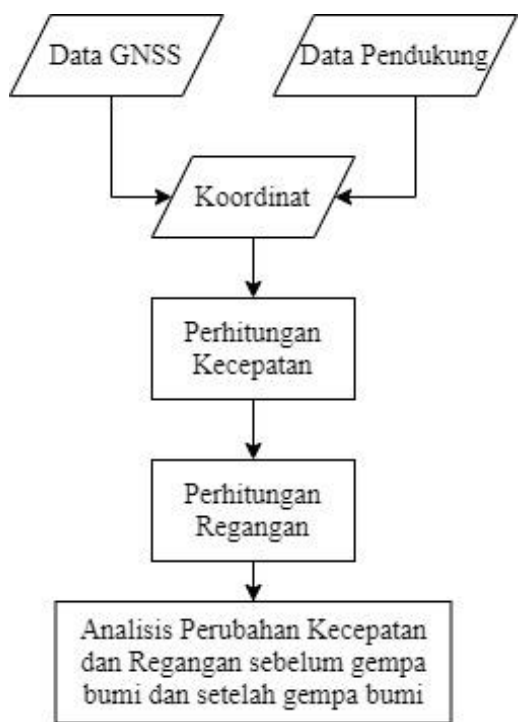

Gambar 3. Diagram alir dari penelitian ini 
Terdapat lima segmen segitiga yang digunakan untuk perhitungan regangan (Tabel 2). Setiap segmen menggunakan dua stasiun di Lempeng Indo-Australia (COCO dan XMIS), dan satu stasiun di Lempeng Sundaland. Setiap segmen dilakukan perhitungan dua kali: sebelum gempa bumi dan setelah gempa bumi. Selain itu, nilai dan arah kecepatan stasiun GNSS di setiap lempeng dilakukan pembahasan dengan membandingkannya dengan nilai dan arah kecepatan dari lempeng terkait.

\section{HASIL}

Tren linear dihasilkan dari pengolahan koordinat baik dari NS component maupun dari EW component. Hal ini menunjukkan stasiun GNSS tidak terpengaruh mekanisme pasca gempa bumi dengan tren logaritmik (Anugrah dkk., 2015).

Tabel 2. Segmen segitiga yang digunakan untuk perhitungan regangan

\begin{tabular}{cccc}
\hline $\begin{array}{c}\text { Nomor } \\
\text { Segmen }\end{array}$ & $\begin{array}{c}\text { Stasiun } \\
\text { GNSS 1 }\end{array}$ & $\begin{array}{c}\text { Stasiun } \\
\text { GNSS 2 }\end{array}$ & Stasiun GNSS 3 \\
\hline 1 & COCO & XMIS & PTLO \\
2 & COCO & XMIS & KRUI \\
3 & COCO & XMIS & PPNJ \\
4 & COCO & XMIS & MLKN \\
5 & COCO & XMIS & LAIS \\
\hline
\end{tabular}

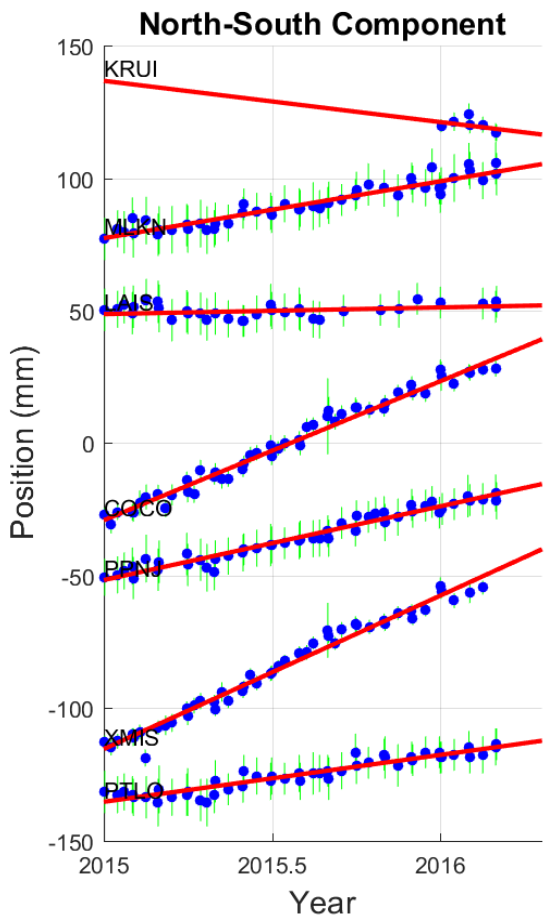

Hasil dari deret waktu koordinat beserta regresi liniear yang dihitung sebelum gempa bumi dan setelah gempa bumi ditunjukkan pada Gambar 4 dan Gambar 5. Deret waktu koordinat yang ditunjukkan merupakan deret waktu koordinat setelah pembuangan data outlier. Proses pembuangan data outlier membuat data dari stasiun KRUI menjadi sangat sedikit sehingga tidak dilakukan perhitungan regangan (segmen 4). Data dengan outlier paling sedikit atau data dengan jumlah hari paling banyak untuk dilakukan perhitungan regangan adalah stasiun COCO dan stasiun XMIS di Lempeng IndoAustralia.

Nilai dan arah kecepatan dari stasiun GNSS yang mengacu ke ITRF2014 mengalami perubahan. Perubahan yang umumnya terjadi di stasiun GNSS adalah berkurangnya nilai kecepatan. Arah kecepatan cenderung sama (perbedaan kurang dari $5^{\circ}$ ) kecuali pada stasiun KRUI. Seperti pembahasan sebelumnya, perubahan arah yang signifikan pada stasiun KRUI disebabkan oleh jumlah data KRUI yang sedikit akibat penghapusan data outlier. Peta kecepatan stasiun GNSS ditunjukkan pada Gambar 6 dan Gambar 7 dengan nilai kecepatan stasiun GNSS beserta nilai perubahan kecepatan ditunjukkan pada Tabel 3.

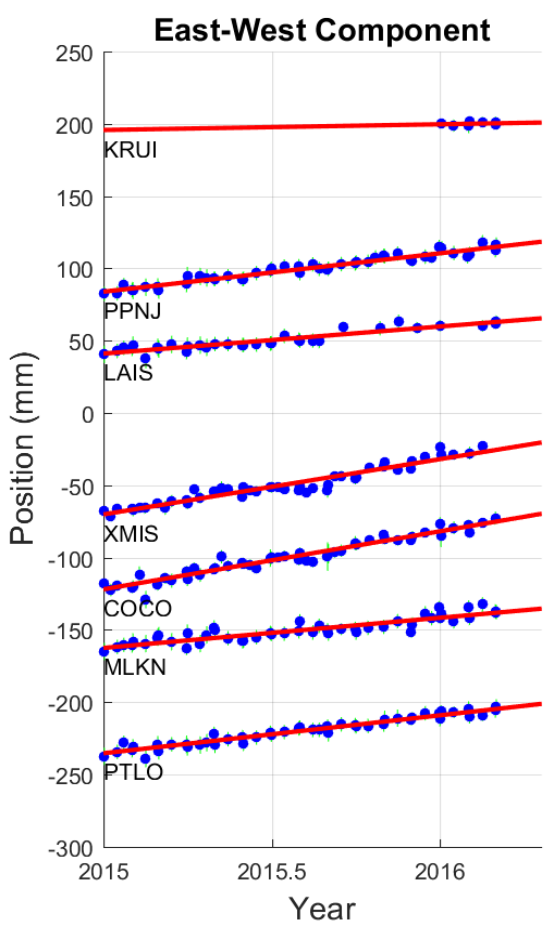

Gambar 4. Deret waktu koordinat stasiun GNSS sebelum gempa bumi Samudera Hindia tahun 2016. 
Tabel 3. Perubahan kecepatan stasiun GNSS sebelum dan setelah gempa bumi Samudera Hindia tahun 2016.

\begin{tabular}{ccccccc}
\hline \multirow{2}{*}{$\begin{array}{c}\text { Nama } \\
\text { Stasiun }\end{array}$} & \multicolumn{2}{c}{$\begin{array}{c}\text { Sebelum Gempa Bumi } \\
(\mathbf{m m} / \text { tahun) }\end{array}$} & \multicolumn{2}{c}{$\begin{array}{c}\text { Setelah Gempa Bumi } \\
(\mathbf{m m} / \text { tahun) }\end{array}$} & \multicolumn{2}{c}{$\begin{array}{c}\text { Nilai Perubahan } \\
\text { (mm/tahun) }\end{array}$} \\
\cline { 2 - 6 } & Kecepatan NS & Kecepatan EW & Kecepatan NS & Kecepatan EW & Kecepatan NS & Kecepatan EW \\
\hline PTLO & 17,60 & 26,20 & 17,40 & 24,50 & $-0,2$ & $-1,7$ \\
KRUI & 12,40 & 7,80 & 1,50 & 12,00 & $-10,9$ & 4,2 \\
PPNJ & 27,80 & 26,50 & 26,30 & 25,50 & $-1,5$ & $-1,0$ \\
MLKN & 21,40 & 20,80 & 17,70 & 17,10 & $-3,7$ & $-3,7$ \\
LAIS & 2,50 & 18,70 & 1,10 & 11,30 & $-1,4$ & $-7,4$ \\
COCO & 52,40 & 40,10 & 52,90 & 44,40 & 0,5 & 4,3 \\
XMIS & 57,80 & 38,20 & 55,10 & 39,80 & $-2,7$ & 1,6 \\
\hline
\end{tabular}
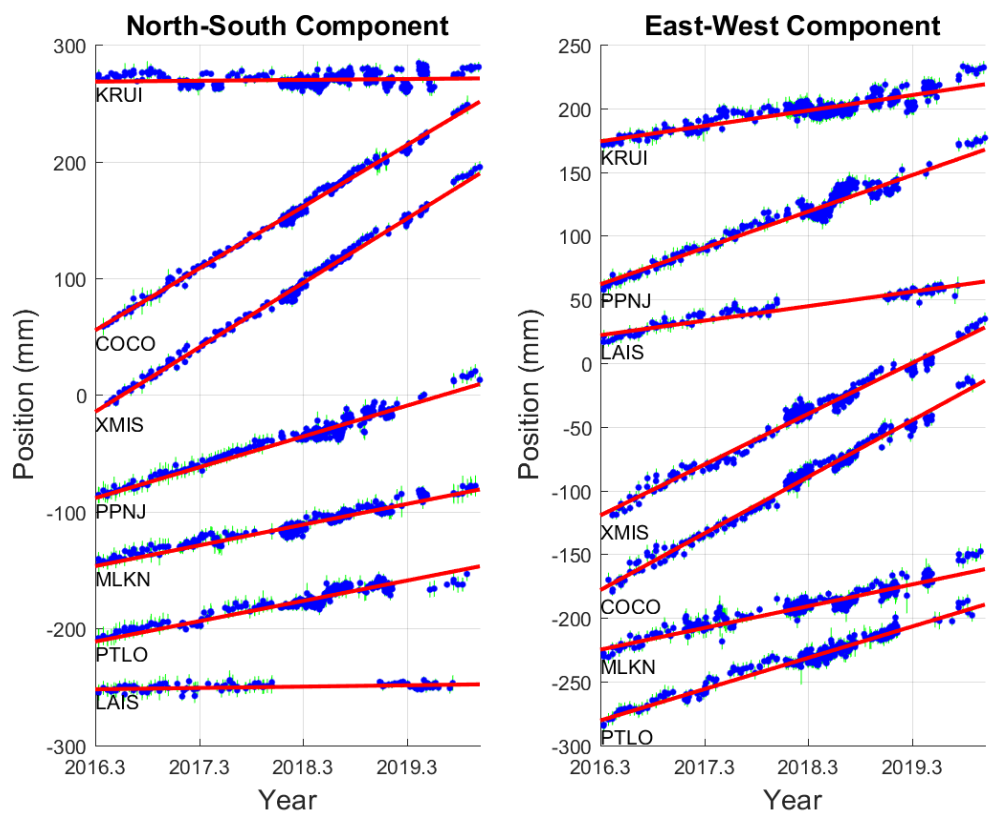

Gambar 5. Deret waktu koordinat stasiun GNSS setelah gempa bumi Samudera Hindia tahun 2016.

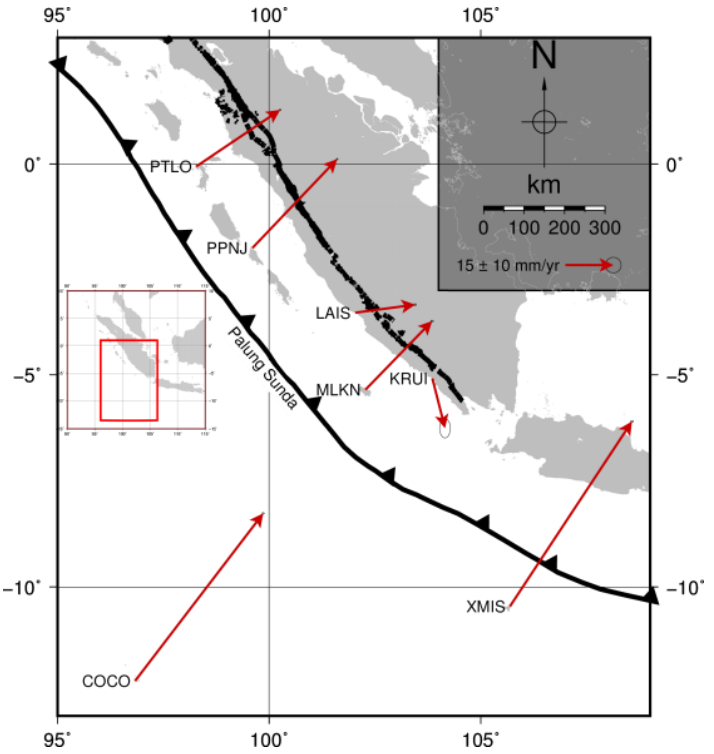

Gambar 6. Nilai dan arah kecepatan stasiun GNSS sebelum gempa bumi Samudera Hindia tahun 2016.

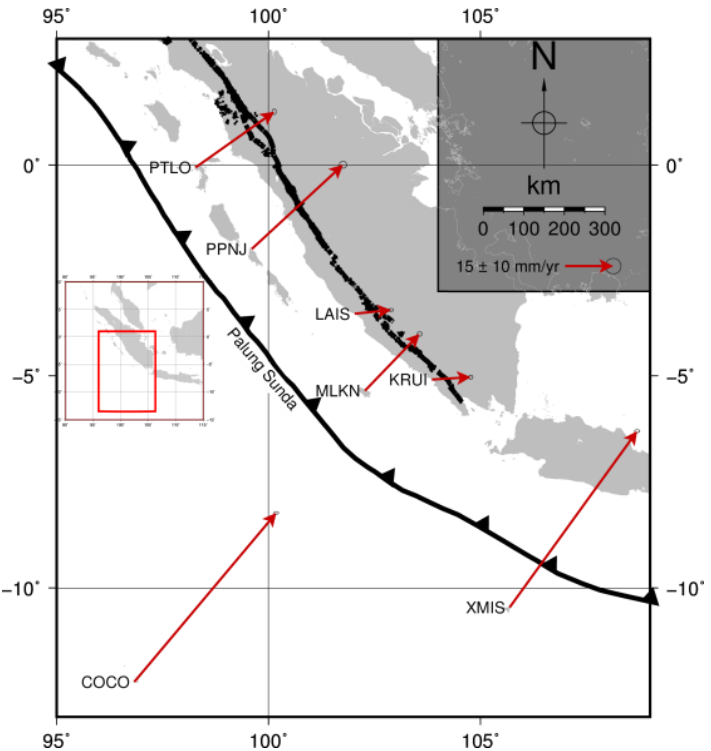

Gambar 7. Nilai dan arah kecepatan stasiun GNSS setelah gempa bumi Samudera Hindia tahun 2016. 
Tabel 4. Perubahan regangan setiap segmen sebelum dan setelah gempa bumi Samudera Hindia tahun 2016.

\begin{tabular}{ccccccc}
\hline \multirow{2}{*}{$\begin{array}{c}\text { Nomor } \\
\text { Segmen }\end{array}$} & \multicolumn{2}{c}{$\begin{array}{c}\text { Sebelum Gempa Bumi } \\
\text { (mikrostrain/tahun) }\end{array}$} & \multicolumn{2}{c}{$\begin{array}{c}\text { Setelah Gempa Bumi } \\
\text { (mikrostrain/tahun) }\end{array}$} & \multicolumn{2}{c}{$\begin{array}{c}\text { Nilai Perubahan } \\
\text { (mikrostrain/tahun) }\end{array}$} \\
\cline { 2 - 7 } & $\begin{array}{c}\text { Regangan } \\
\text { Utama 1 }\end{array}$ & $\begin{array}{c}\text { Regangan } \\
\text { Utama 2 }\end{array}$ & $\begin{array}{c}\text { Regangan } \\
\text { Utama 1 }\end{array}$ & $\begin{array}{c}\text { Regangan } \\
\text { Utama 2 }\end{array}$ & $\begin{array}{c}\text { Regangan } \\
\text { Utama 1 }\end{array}$ & $\begin{array}{c}\text { Regangan } \\
\text { Utama 2 }\end{array}$ \\
\hline 1 & 0,009 & $-2,700$ & 0,130 & $-2,770$ & 0,121 & $-0,070$ \\
3 & 0,040 & $-2,450$ & 0,060 & $-2,620$ & 0,020 & $-0,170$ \\
4 & 0,420 & $-5,410$ & 0,520 & $-5,940$ & 0,100 & $-0,530$ \\
5 & 0,280 & $-6,250$ & 0,400 & $-6,410$ & 0,120 & $-0,160$ \\
\hline
\end{tabular}

Jenis perubahan kecepatan yang terjadi adalah penurunan kecepatan. Hal ini ditunjukkan dengan nilai perubahan kecepatan yang bernilai negatif baik di komponen NS maupun komponen EW. Nilai perubahan yang positif atau terjadi peningkatan kecepatan terdapat pada stasiun COCO. Hal ini diduga karena stasiun COCO terletak relatif lebih jauh dari Palung Sunda atau zona subduksi dibandingkan stasiun lainnya. Hasil perubahan nilai regangan menunjukkan pertambahan nilai pemendekan yang terjadi antara Lempeng Indo-Australia dan Lempeng Sundaland. Hal ini menunjukkan Lempeng Indo-Australia mendekat lebih cepat setelah gempa bumi Samudera Hindia tahun 2016. Nilai regangan dari setiap segmen beserta nilai perubahan regangan ditunjukkan pada Tabel 4. Regangan utama 1 merupakan komponen pemanjangan dan bernilai positif. Regangan utama 2 merupakan komponen pemendekkan dan bernilai negatif. Semua segmen menunjukkan terjadi pertambahan nilai pemendekkan dan mengalami pemendekkan jauh lebih besar dibandingkan pemanjangan. Hal ini disebabkan karena arah dari proses subduksi yang menyebabkan kedua lempeng semakin dekat. Pertambahan nilai pemendekkan terbesar terjadi di segmen 4 yang menghubungkan stasiun COCO, XMIS, dan MLKN. Pertambahan nilai pemendekkan terkecil terjadi di segmen 1 yang menghubungkan stasiun COCO, XMIS, dan PTLO.

\section{PEMBAHASAN}

Penurunan nilai kecepatan dan pertambahan nilai pemendekkan nilai regangan diduga kuat merupakan implikasi tektonik dari gempa bumi Samudera Hindia tahun 2016. Hal ini dikarenakan perubahan yang terjadi konsisten di semua stasiun dan semua segmen yang dilakukan perhitungan. Perubahan terbesar terjadi di stasiun MLKN dan segmen yang menggunakan stasiun MLKN. Hal ini diduga karena stasiun MLKN terletak relatif lebih dekat dari Palung Sunda dibandingkan dengan stasiun lainnya. Hal ini konsisten dengan pembahasan sebelumnya yaitu stasiun COCO merupakan satu-satunya stasiun dengan penambahan nilai kecepatan karena lokasinya yang relatif lebih jauh. Hal ini menunjukkan gempa bumi Samudera Hindia tahun 2016 memberikan implikasi tektonik lebih besar di wilayah yang lebih dekat dengan Palung Sunda.

Arah kecepatan stasiun di Lempeng Sundaland yang mengacu ke ITRF2014 umumnya berbeda signifikan dengan arah kecepatan Lempeng Sundaland. Sebaliknya, arah kecepatan semua stasiun di Lempeng IndoAustralia sama dengan arah kecepatan Lempeng Indo-Australia yaitu ke arah timur laut (Hanifa dkk., 2014). Nilai kecepatan Lempeng IndoAustralia yaitu 65-69 mm/tahun yang lebih besar dibandingkan kecepatan subduksinya yaitu sebesar 44-48 mm/tahun (DeMets dkk., 2010). Nilai kecepatan lempeng tersebut konsisten dengan nilai kecepatan lempeng dari Hanifa dkk. (2014) yaitu sebesar $68 \mathrm{~mm} / \mathrm{tahun}$. Arah kecepatan Lempeng Sundaland yaitu ke arah timur-tenggara (Yong dkk., 2017). Stasiun di Lempeng Sundaland yang mengarah ke timurtenggara hanya stasiun LAIS dan stasiun KRUI setelah gempa bumi. Data stasiun KRUI setelah gempa bumi jauh lebih banyak dibandingkan data stasiun KRUI sebelum gempa bumi. Hal ini membuat stasiun KRUI dapat digunakan untuk pembahasan arah kecepatan meskipun tidak bisa digunakan untuk pembahasan perubahan nilai kecepatan dan regangan.

Dua stasiun yang mengarah sama dengan pergerakan Lempeng Sundaland merupakan stasiun yang berada di Pulau Sumatra. Hal ini menunjukkan tiga stasiun yang berada pada pulau di sebelah barat Pulau Sumatra berada di lempeng yang belum banyak didefinisikan 


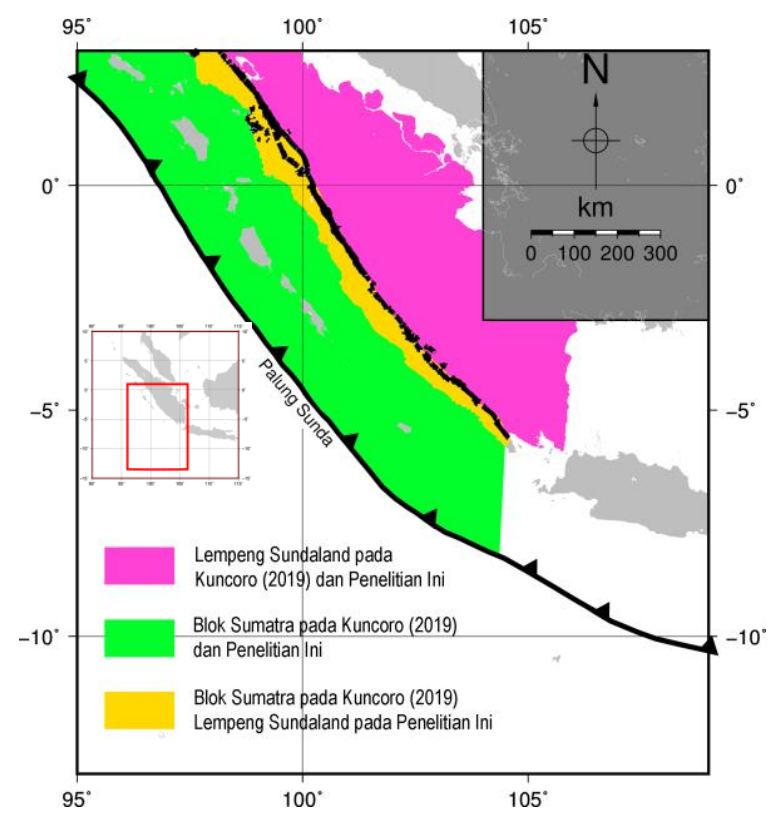

Gambar 8. Perbedaan pendefinisian Blok Sumatra antara penelitian ini dan Kuncoro dkk. (2019).

sebagai lempeng yang berbeda dengan Lempeng Sundaland. Salah satu penelitian yang membedakan Lempeng Sundaland sebagai lempeng/blok yang berbeda yaitu penelitian Kuncoro dkk. (2019) yang juga menggunakan data GNSS. Kuncoro menunjukkan blok Sumatra terpisah dari Lempeng Sundaland dengan sesar Sumatra sebagai pemisah blok Sumatra dan Lempeng Sundaland. Namun, dari hasil penelitian ini, seluruh wilayah di Pulau Sumatra, termasuk di sebelah barat Pulau Sumatra, termasuk dalam Lempeng Sundaland. Blok Sumatra dari hasil penelitian ini melingkupi pulau-pulau kecil di sebelah barat Pulau Sumatra. Perbedaan penentuan Blok Sumatra tersebut ditunjukkan pada Gambar 8.

\section{KESIMPULAN}

Gempa bumi Samudera Hindia tahun 2016 menyebabkan penurunan nilai kecepatan dan pertambahan nilai pemendekkan di stasiun GNSS di sekitar Palung Sunda. Kecepatan stasiun GNSS yang diperoleh berkisar 18 hingga $70 \mathrm{~mm} /$ tahun. Perubahan kecepatan dan regangan semakin besar pada stasiun yang mendekati Palung Sunda. Penelitian ini membuktikan gempa bumi dengan magnitudo di atas 7 memberikan implikasi tektonik yang luas. Arah kecepatan stasiun yang berada di pulau di sebelah barat Pulau Sumatra diduga berada di Blok Sumatra, pecahan dari Lempeng
Sundaland. Pendefinisan blok baru ini dibuktikan oleh dua penelitian dengan data GNSS sehingga perlu diperkuat dengan penelitian geologi dan geofisika.

\section{UCAPAN TERIMA KASIH}

Ucapan terima kasih diberikan kepada seluruh pihak yang terlibat dalam pengumpulan data dan pengolahan data. Penelitian ini didanai hibah GBU45 ITERA tahun 2021. Gambar dibuat menggunakan Generic Mapping Tools (Wessel dan Smith, 2013).

\section{DAFTAR PUSTAKA}

Alif, S.M., Meilano, I., Gunawan, E. dan Efendi, J., 2016. Evidence of postseismic deformation signal of the 2007 M8. 5 Bengkulu earthquake and the 2012 M8. 6 Indian Ocean earthquake in Southern Sumatra, Indonesia, based on GPS data. Journal of Applied Geodesy,10(2), hal.103-108. DOI: 10.1515/jag-2015-0019

Alif, S.M., Fattah, E.I. and Kholil, M., 2020 a. Geodetic slip rate and locking depth of east Semangko Fault derived from GPS measurement. Geodesy

Geodynamics, 11(3),

and https://doi.org/10.1016/j.geog.2020.04.002

Alif, S.M., Yosua, E., Fauzi, A.I. and Leksono, B.E., 2020b. Association between Surface Air Temperature And Land Use On The Campus Scale. Journal of Geoscience, Engineering, Environment, and Technology, 5(3), hal.147-154. DOI: https://doi.org/10.25299/jgeet.2020.5.3.5187

Alif, S.M., Fattah, E.I., Kholil, M. dan Anggara, O., 2021a. Source of the 2019 Mw6.9 Banten Intraslab earthquake modelled with GPS data inversion. Geodesy and Geodynamics, 12(4), hal.308-314.

https://doi.org/10.1016/ j.geog.2021.06.001

Alif, S.M., Saraswati, N.R. dan Perdana, R.S., 2021b, September. Identification of Capable Fault Location around Mount Betung Area Based on GPS Strain Data. IOP Conference Series: Earth and Environmental Science, 830(1), 012040.

Altamimi, Z., Rebischung, P., Métivier, L. and Collilieux, X., 2016. ITRF2014: A new release of the International Terrestrial Reference Frame modeling nonlinear station motions. Journal of Geophysical Research: 
Solid Earth, 121(8), pp.6109-6131. https://doi.org/10.1002/ 2016JB013098

Anugrah, B., Meilano, I., Gunawan, E. dan Efendi, J., 2015. Estimation of postseismic deformation parameters from continuous GPS data in northern Sumatra after the 2004 Sumatra-Andaman earthquake. Earthquake Science, 28(5), pp.347-352. DOI: 10.1007/s11589-015-0136-X

DeMets, C., Gordon, R.G. dan Argus, D.F., 2010. Geologically current plate motions. Geophysical Journal International, 181(1), pp.1-80. https://doi.org/10.1111/j.1365246X.2009.04491.x

Devoti, R., Esposito, A., Pietrantonio, G., Pisani, A.R. dan Riguzzi, F., 2011. Evidence of large scale deformation patterns from GPS data in the Italian subduction boundary. Earth and Planetary Science Letters, 311(3-4), pp.230241. DOI: 10.1016/j.epsl.2011.09.034

Griffin, J., Nguyen, N., Cummins, P. dan Cipta, A., 2019. Historical earthquakes of the eastern Sunda Arc: Source mechanisms and intensity-based testing of Indonesia's national seismic hazard assessment. Bulletin of the Seismological Society of America, 109(1), https://doi.org/10.1785/0120180085

Hanifa, N.R., Sagiya, T., Kimata, F., Efendi, J., Abidin, H.Z. dan Meilano, I., 2014. Interplate coupling model off the southwestern coast of Java, Indonesia, based on continuous GPS data in 2008-2010. Earth and Planetary Science Letters, 401, hal.159-171. https://doi.org/10.1016/j.eps1.2014.06.010

Hayes, G.P., Moore, G.L., Portner, D.E., Hearne, M., Flamme, H., Furtney, M. dan Smoczyk, G.M., 2018. Slab2, a comprehensive subduction zone geometry model. Science, 362(6410), hal.58-61. DOI: $10.1126 /$ science.aat4723

Heidarzadeh, M., Harada, T., Satake, K., Ishibe, T. dan Takagawa, T., 2017. Tsunamis from strike-slip earthquakes in the Wharton Basin, northeast Indian Ocean: March 2016 M w7. 8 event and its relationship with the April 2012 M w 8.6 event. Geophysical Journal International, 211(3), hal.1601-1612. https://doi.org/10.1093/gji/ggx395

Herring, T.A., King, R.W. dan McClusky, S.C., 2010.

Introduction
GAMIT/GLOBK. Massachusetts Institute of Technology, Cambridge, Massachusetts.

Johnston, G., Riddell, A. dan Hausler, G., 2017. The international GNSS service. Springer handbook of global navigation satellite systems. Springer International Publishing, hal.967-982.

Kuncoro, H., Meilano, I. dan Susilo, S., 2019. Sunda and Sumatra Block Motion in ITRF2008. E3S Web of Conferences, 94, p. 04006.

Maulida, P., Meilano, I., Gunawan, E. dan Efendi, J., 2016, May. Analysis of 2012 M8. 6 Indian Ocean earthquake coseismic slip model based on GPS data. AIP Conference Proceedings, 1730(1), p.040006). Publishing LLC. DOI: 10.1063/1.4947396

McCaffrey, R., 2009. The tectonic framework of the Sumatran subduction zone. Annual Review of Earth and Planetary Sciences, 37, hal.345-366.

DOI: 10.1146/annurev.earth.031208.100212

McLoughlin, I.V., Wong, K.J. dan Tan, S.L., 2011. Data collection, communications and processing in the Sumatran GPS array (SuGAr). Proceedings of the World Congress on Engineering, 2, hal. 6-8).

Pinasti, A., Widjajanti, N., Pratama, C., Parseno, P., Lestari, D., Sunantyo, A., Heliani, L. dan Ulinnuha, H., 2019, July. Crustal Deformation Pattern across Yogyakarta Special Region Revealed by a Dense Geodetic Measurements. 5th International Conference on Science and Technology (ICST), 1, hal.1-5.

Pratama, C., Ito, T., Sasajima, R., Tabei, T., Kimata, F., Gunawan, E., Ohta, Y., Yamashina, T., Ismail, N., Nurdin, I. and Sugiyanto, D., 2017. Transient rheology of the oceanic asthenosphere following the 2012 Indian Ocean Earthquake inferred from geodetic data. Journal of Asian Earth Sciences, 147, hal.50-59. https://doi.org/10.1016/j.jseaes.2017.07.049

Stern, R.J., 2002. Subduction zones. Reviews of geophysics, 40(4), hal.3-1.

Wang, K., Hu, Y. dan He, J., 2012. Deformation cycles of subduction earthquakes in a viscoelastic Earth. Nature, 484(7394), hal.327-332.

https://doi.org/10.1038/nature11032

Wessel, P., Smith, W.H., Scharroo, R., Luis, J. dan Wobbe, F., 2013. Generic mapping tools: 
improved version released. Eos, Transactions American Geophysical Union,94(45), hal.409-410.

https://doi.org/10.1002/2013EO450001
Yong, C.Z., Denys, P.H. dan Pearson, C.F., 2017. Present-day kinematics of the Sundaland plate. Journal of Applied Geodesy, 11(3), hal.169-177. https://doi.org/10.1515/jag-2016-0024. 